\title{
Effects of hierarchical structure on the performance of tin oxide-supported platinum catalyst for room-temperature formaldehyde oxidation
}

\author{
Yuanyuan Duan a, Shaoqing Song b , Bei Cheng a, Jiaguo Yu a,c,*, Chuanjia Jiang a,\# \\ a State Key Laboratory of Advanced Technology for Materials Synthesis and Processing, Wuhan University of Technology, Wuhan 430070, Hubei, China \\ b Key Laboratory of Radioactive Geology and Exploration Technology Fundamental Science for National Defense, School of Chemistry, Biology and Mate- \\ rial, East China University of Technology, Nanchang, 330013, Jiangxi, China \\ c Department of Physics, Faculty of Science, King Abdulaziz University, Jeddah 21589, Saudi Arabia
}

\section{A R T I C L E I N F}

\section{Article history:}

Received 22 August 2016

Accepted 6 October 2016

Published 5 February 2017

\section{Keywords:}

Formaldehyde catalytic oxidation

Room temperature

Tin oxide

Platinum

Hierarchical structure

Flower-like

\begin{abstract}
A B S T R A C T
Flower-like tin oxide-supported platinum $\left(\mathrm{Pt} / \mathrm{SnO}_{x}\right)$ with a hierarchical structure was synthesized by a hydrothermal method and characterized by XRD, SEM, TEM, high resolution TEM, XPS and nitrogen adsorption. The flower-like $\mathrm{Pt} / \mathrm{SnO}_{x}$ microspheres of $1 \mu \mathrm{m}$ in diameter were composed of staggered petal-like nanosheets with a thickness of $20 \mathrm{~nm}$. Pt nanoparticles (NPs) of 2-3 nm were well dispersed on the $\mathrm{SnO}_{x}$ nanosheets. The catalyst was tested in the catalytic oxidation of gaseous formaldehyde (HCHO) at room temperature, and exhibited enhanced activity compared to Pt NPs supported on commercial $\mathrm{SnO}$ and ground $\mathrm{SnO}_{x}$. $\mathrm{HCHO}$ removal of $87 \%$ was achieved over the hierarchical Pt/SnO $x$ after $1 \mathrm{~h}$ of reaction, which was 1.5 times that over the ground $\mathrm{SnO}_{x}$-supported $\mathrm{Pt}\left(\mathrm{Pt} / \mathrm{g}-\mathrm{SnO}_{x}\right)$, and the high activity was maintained after six recycles, showing the high stability of this catalyst. HCHO decomposition kinetics was modeled as a second order reaction. The reaction rate constant for $\mathrm{Pt} / \mathrm{SnO}_{x}$ was 5.6 times higher than $\mathrm{Pt} / \mathrm{g}-\mathrm{SnO}_{x}$. The hierarchical pore structure was beneficial for the diffusion and adsorption of HCHO molecules, and the highly dispersed Pt NPs on the $\mathrm{SnO}_{x}$ nanosheets were the active sites for the oxidative decomposition of $\mathrm{HCHO}$ into $\mathrm{CO}_{2}$ and $\mathrm{H}_{2} \mathrm{O}$. This study provided a promising approach for designing efficient catalysts for indoor $\mathrm{HCHO}$ removal at ambient temperature.
\end{abstract}

(C) 2016, Dalian Institute of Chemical Physics, Chinese Academy of Sciences. Published by Elsevier B.V. All rights reserved.

\section{Introduction}

Formaldehyde (HCHO) is a hazardous pollutant common in indoor air, which is emitted from building and decoration materials [1-3]. In the last decade, many efforts have been made for developing methods for gaseous HCHO removal, including adsorption [4-6], photocatalytic oxidation [7-11] and catalytic oxidative decomposition [12-29]. Among these methods, catalytic oxidation is appealing because $\mathrm{HCHO}$ is continuously decomposed into harmless carbon dioxide $\left(\mathrm{CO}_{2}\right)$ and water $\left(\mathrm{H}_{2} \mathrm{O}\right)$ over well designed catalysts at low temperature and with low energy use [30,31]. Most of the catalysts capable of

\footnotetext{
* Corresponding author. Tel.: +86-27-87871029; Fax: +86-27-87879468; E-mail: jiaguoyu@yahoo.com

\# Corresponding author. Tel.: +86-27-87871029; Fax: +86-27-87879468; E-mail: jiangcj2016@yahoo.com

This work was supported by the National Natural Science Foundation of China $(51320105001,51372190,21573170,51272199,21433007)$, the National Basic Research Program of China (973 program, 2013CB632402), the Natural Science Foundation of Hubei Province (2015CFA001), the Fundamental Research Funds for the Central Universities (WUT: 2015-III-034) and Innovative Research Funds of SKLWUT (2015-ZD-1).

DOI: 10.1016/S1872-2067(16)62551-2 | http://www.sciencedirect.com/science/journal/18722067 | Chin. J. Catal., Vol. 38, No. 2, February 2017
} 
room-temperature HCHO decomposition are supported noble metals, such as platinum (Pt) [12-18], palladium (Pd) [19,20], gold $(\mathrm{Au})$ [21-23] and silver $(\mathrm{Ag})$ [24], while recently non-noble metal materials such as manganese oxide have been reported to have high $\mathrm{HCHO}$ decomposition activity at room temperature [25-27].

Besides the selection of the active component with an intrinsic high activity [21,32], various strategies have been adopted to improve the performance of catalytic HCHO oxidation, such as increasing the dispersion of the noble metal, removing residual halogen ions, enhancing metal-support interaction, and increasing HCHO adsorption affinity (e.g. by introducing a higher amount of surface hydroxyl) $[16,19,33]$. In addition to the above factors, which focus on the chemical properties of the catalyst, the diffusion of reactants and products to and from the catalyst interior also plays a key role in determining the rate of catalytic reactions $[34,35]$. Thus, materials with a hierarchical structure of different length scales have come to the attention of researchers, due to the efficient mass transfer within the hierarchical architecture [36,37]. Hierarchical micro- and nanostructures have recently attracted considerable interest in many fields, such as energy conversion and storage [38,39], gas sensor [40], adsorptive removal of water pollutants $[41,42]$, as well as environmental catalysis and photocatalysis [8,36,43-50].

Catalysts with hierarchical structures can take various forms, e.g. a nanofiber mat [36], assembly of lab-synthesized or commercial nanoparticles [8,37], and open-ended macroporous channels [43]. These different morphologies would influence the catalytic performance [44]. Here, we report the fabrication of flower-like tin oxide-supported platinum $\left(\mathrm{Pt} / \mathrm{SnO}_{x}\right)$ with a hierarchical structure for the catalytic oxidation of $\mathrm{HCHO}$ into $\mathrm{CO}_{2}$ and $\mathrm{H}_{2} \mathrm{O}$ at room temperature. The hierarchical $\mathrm{SnO}_{x}$ with the flower-like morphology was beneficial for the transport and adsorption of HCHO molecules, and the highly dispersed Pt nanoparticles (NPs) were active components for HCHO decomposition. This research can help the design of a catalyst for efficient air purification at ambient temperature.

\section{Experimental}

\subsection{Preparation of catalysts}

All chemicals were analytical grade and used without further purification. In a typical procedure to synthesize the flower-like $\mathrm{SnO}_{x}, 3.2 \mathrm{mmol}$ of $\mathrm{SnF}_{2}$ and $12.8 \mathrm{mmol}$ of urea were added into $160 \mathrm{~mL}$ of deionized water and stirred for $0.5 \mathrm{~h}$. The mixed solution was then transferred into a dried $200 \mathrm{~mL}$ Teflon-lined stainless steel autoclave and kept at $180{ }^{\circ} \mathrm{C}$ for $18 \mathrm{~h}$. After the hydrothermal reaction, the grey precipitate was collected by centrifugation, washed with distilled water and ethanol three times, and dried in an oven at $80^{\circ} \mathrm{C}$ for $6 \mathrm{~h}$.

To investigate the role of the hierarchical structure on $\mathrm{HCHO}$ oxidation performance, two additional types of $\mathrm{SnO}_{x}$ were used as the catalyst support for comparison, namely, a commercial tin(II) oxide ( $\mathrm{SnO}$ ) (denoted as c-SnO) and ground flower-like $\mathrm{SnO}_{x}\left(\mathrm{~g}-\mathrm{SnO}_{x}\right)$. Specifically, to prepare the $\mathrm{g}$-SnO ${ }_{x}$ sample, a portion of the flower-like $\mathrm{SnO}_{x}$ was suspended in ethanol and ground in a ball mill (QM-3SP04) for $6 \mathrm{~h}$.

To synthesize the $\mathrm{SnO}_{x}$-supported Pt catalyst, $1 \mathrm{~g}$ of the $\mathrm{SnO}_{x}$ support (flower-like $\mathrm{SnO}_{x}, \mathrm{c}-\mathrm{SnO}$ or $\mathrm{g}-\mathrm{SnO}_{x}$ ) was dispersed into $10 \mathrm{~mL}$ of deionized water by ultrasonic treatment, and $2.65 \mathrm{~mL}$ of $\mathrm{H}_{2} \mathrm{PtCl}_{6} \cdot 6 \mathrm{H}_{2} \mathrm{O}$ solution ( $1 \mathrm{wt} \%$ ) was added into the suspension under magnetic stirring. After impregnation for $1 \mathrm{~h}, 2.5 \mathrm{~mL}$ of a mixed solution of $\mathrm{NaBH}_{4}(0.1 \mathrm{~mol} / \mathrm{L})$ and $\mathrm{NaOH}(0.5 \mathrm{~mol} / \mathrm{L})$ was quickly added into the suspension under vigorous stirring for $0.5 \mathrm{~h}$. The precipitate obtained was washed with deionized water twice, and then dried at $80{ }^{\circ} \mathrm{C}$ for $12 \mathrm{~h}$. The samples obtained with the different $\mathrm{SnO}_{x}$ supports were denoted as $\mathrm{Pt} / \mathrm{SnO}_{x}, \mathrm{Pt} / \mathrm{c}-\mathrm{SnO}$ and $\mathrm{Pt} / \mathrm{g}-\mathrm{SnO}_{x}$, respectively.

\subsection{Characterization}

The morphology and structure of the samples were characterized by field emission scanning electron microscope (FESEM) (S-4800), transmission electron microscopy (TEM) (JEOL-JEM-2100F) and high resolution TEM (HRTEM) (JEM-2100). The elemental composition of the $\mathrm{Pt} / \mathrm{SnO}_{x}$ sample was determined by an energy dispersive X-ray spectroscopy (EDX) module attached to the TEM. The phase structure was analyzed by X-ray diffraction (XRD) (Rigaku, D/Max-RB, Japan) with $\mathrm{Cu} K_{\alpha}$ radiation at a scan rate $(2 \theta)$ of $0.05^{\circ} / \mathrm{s}$. The surface chemical state of the samples was analyzed by X-ray photoelectron spectroscopy (XPS) (VG ESCALAB 210). The Brunauer-Emmett-Teller (BET) specific surface area and pore volume were measured by $\mathrm{N}_{2}$ adsorption at $-196{ }^{\circ} \mathrm{C}$ (Micromeritics ASAP 2020). The pore size distribution was calculated from the adsorption branch of the $\mathrm{N}_{2}$ adsorption isotherm by the Barret-Joyner-Halender (BJH) method.

\subsection{Catalytic test}

The catalytic HCHO oxidation tests were performed in the dark at room temperature $\left(25^{\circ} \mathrm{C}\right)$. In each experiment, $0.1 \mathrm{~g}$ of catalyst was dispersed on the bottom of a glass Petri dish $(8 \mathrm{~cm}$ diameter), which was placed in a $6 \mathrm{~L}$ organic glass box and covered with a glass slide. Then, the box reactor was sealed, and $12 \mu \mathrm{L}$ of condensed $\mathrm{HCHO}$ solution (38\%) was injected into the reactor. A fan was turned on to accelerate the volatilization of HCHO, and the HCHO concentration in the reactor was stabilized at 172-177 ppm after $1 \mathrm{~h}$. Then, the glass slide on the Petri dish was removed to start the catalytic oxidation reaction. The concentrations of $\mathrm{HCHO}, \mathrm{CO}_{2}, \mathrm{CO}$ and water vapor were monitored online with a photoacoustic field gas monitor (INNOVA AirTech Instruments, Model 1412). The HCHO removal ratio $(\eta)$ was calculated by equation:

$$
\eta(\%)=\frac{C_{0}-C_{\text {final }}}{C_{0}} \times 100
$$

where $C_{0}$ is the initial $\mathrm{HCHO}$ concentration, and $C_{\text {final }}$ is the final HCHO concentration.

\section{Results and discussion}




\subsection{Morphology and phase structures}

Fig. 1 shows the FESEM and TEM images of the $\mathrm{SnO}_{x}$ and $\mathrm{Pt} / \mathrm{SnO}_{x}$ samples. In Fig. 1(a), the sample exhibited a flower-like hierarchical microsphere morphology approximately $1 \mu \mathrm{m}$ in diameter, which was composed of staggered petal-like nanosheets with a thickness of $20 \mathrm{~nm}$ (inset of Fig. 1(a)). In the $\mathrm{Pt} / \mathrm{SnO}_{x}$ sample, the flower-like hierarchical architecture was not destroyed, and Pt NPs with diameters of 2-3 nm were deposited on the petal-like nanosheets with high dispersion (Fig. 1(b)).

The HRTEM image (Fig. 1(c)) shows lattice fringes with spacing of $0.30,0.27$ and $0.18 \mathrm{~nm}$, corresponding to the (101), (110) and (112) planes of SnO, respectively. The lattice fringe spacing of the Pt NPs was $0.22 \mathrm{~nm}$, which can be ascribed to the (111) plane of metallic Pt [36]. The EDX spectrum of the $\mathrm{Pt} / \mathrm{SnO}_{x}$ sample (Fig. 1(d)) indicated that the sample contained $\mathrm{Sn}, \mathrm{O}$ and low levels of $\mathrm{Pt}$, while the peaks for $\mathrm{Cu}$ originated from the $\mathrm{Cu}$ TEM grid.

The FESEM (Fig. 2(a)) and TEM (Fig. 2(b)) images of the ground samples indicated that the hierarchical architecture of flower-like $\mathrm{SnO}_{x}$ was destroyed by ball-milling, and the diameter of the microspheres became smaller. High magnification TEM image (Fig. 2(c)) confirmed that Pt NPs were loaded on the $\mathrm{g}^{-\mathrm{SnO}_{x}}$ support uniformly. From the HRTEM image (Fig. 2(d)), the lattice fringes of the (101) and (110) planes of SnO were still observed, with spacings of 0.30 and $0.27 \mathrm{~nm}$. The Pt NPs were also 2-3 nm in diameter, with lattice fringe spacing of $0.22 \mathrm{~nm}$. These results showed that grinding destroyed the hierarchical architecture of the flower-like $\mathrm{SnO}_{x}$ but did not change the phase structure of $\mathrm{SnO}_{x}$ or the particle size and dispersion of the Pt NPs.

In Fig. 3, the XRD patterns of both $\mathrm{SnO}_{x}$ and $\mathrm{Pt} / \mathrm{SnO}_{x}$ samples showed peaks at $18.3^{\circ}, 29.9^{\circ}, 33.3^{\circ}, 37.2^{\circ}, 47.8^{\circ}, 50.8^{\circ}, 57.4^{\circ}$ and $62.5^{\circ}$, corresponding to the (001), (101), (110), (002), (200), (112), (211) and (103) planes of the tetragonal phase of romarchite (SnO) (JCPDS 06-0395). Meanwhile, small peaks
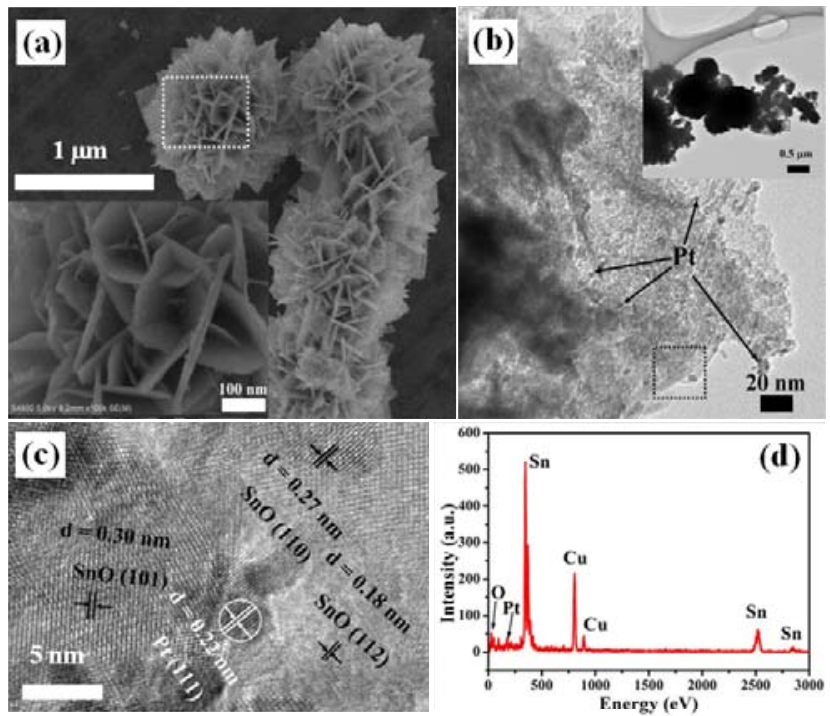

Fig. 1. FESEM image of $\mathrm{SnO}_{x}(\mathrm{a})$; TEM (b), HRTEM (c) images and EDX spectrum (d) of Pt/SnO.

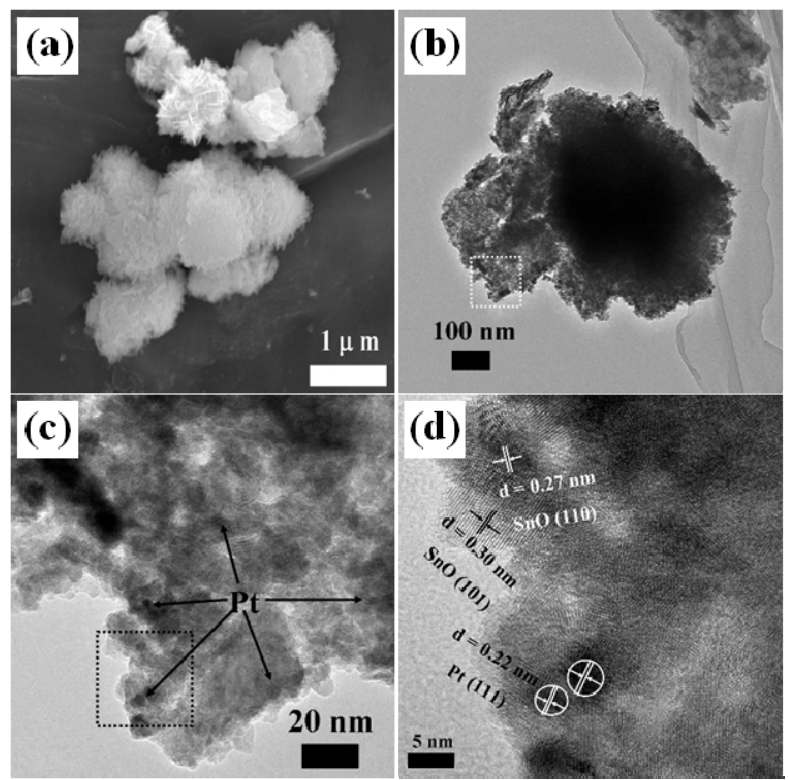

Fig. 2. FESEM image of g-SnO $O_{x}(a)$; TEM $(b, c)$ and HRTEM (d) images of $\mathrm{Pt} / \mathrm{g}-\mathrm{SnO}_{x}$.

were observed at $26.7^{\circ}(110), 34.1^{\circ}$ (101) and $52.1^{\circ}$ (211), which corresponded to the three major peaks of rutile tetragonal tin(IV) oxide ( $\mathrm{SnO}_{2}$ ) (JCPDS 41-1445). These results suggested that the prepared $\mathrm{SnO}_{x}$ was composed of $\mathrm{SnO}$ as the bulk phase with trace contents of $\mathrm{SnO}_{2}$. When Pt NPs were loaded, the intensity of the diffraction peaks became weaker, which was due to the shielding effect of the Pt NPs on the incident and diffracted X-rays [51]. On the other hand, no diffraction peak of Pt was observed due to the low loading and small particle size of Pt on $\mathrm{SnO}_{x}$ [16].

\subsection{Surface chemistry}

The surface composition and chemical state of the $\mathrm{Pt} / \mathrm{SnO}_{x}$ sample were further investigated by XPS. Fig. 4(a) shows the Sn $3 d$ spectrum of the $\mathrm{Pt} / \mathrm{SnO}_{x}$ sample with two main peaks at 487.4 and $495.8 \mathrm{eV}$ corresponding to $\mathrm{Sn} 3 d_{5 / 2}$ and $\mathrm{Sn} 3 d_{3 / 2}$ lev-

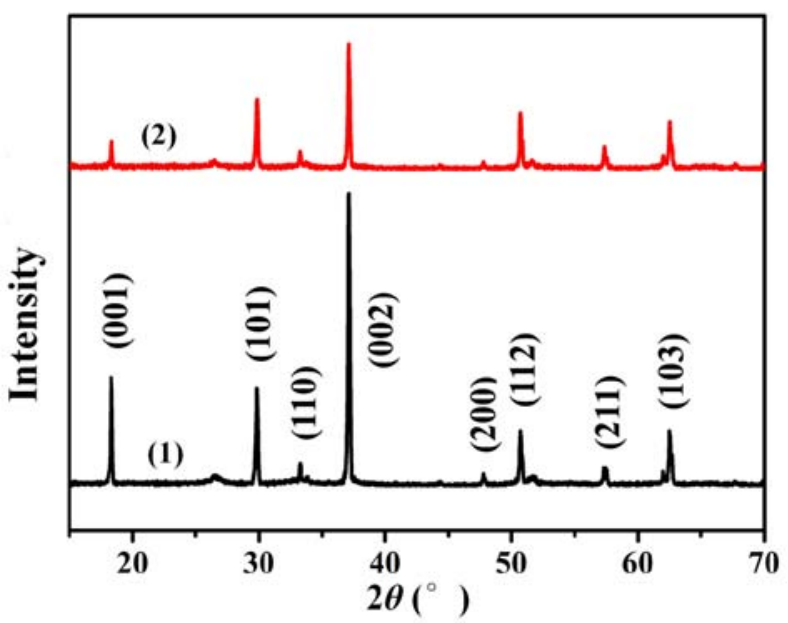

Fig. 3. XRD patterns of $\mathrm{SnO}_{x}(1)$ and $\mathrm{Pt} / \mathrm{SnO}_{x}(2)$. 

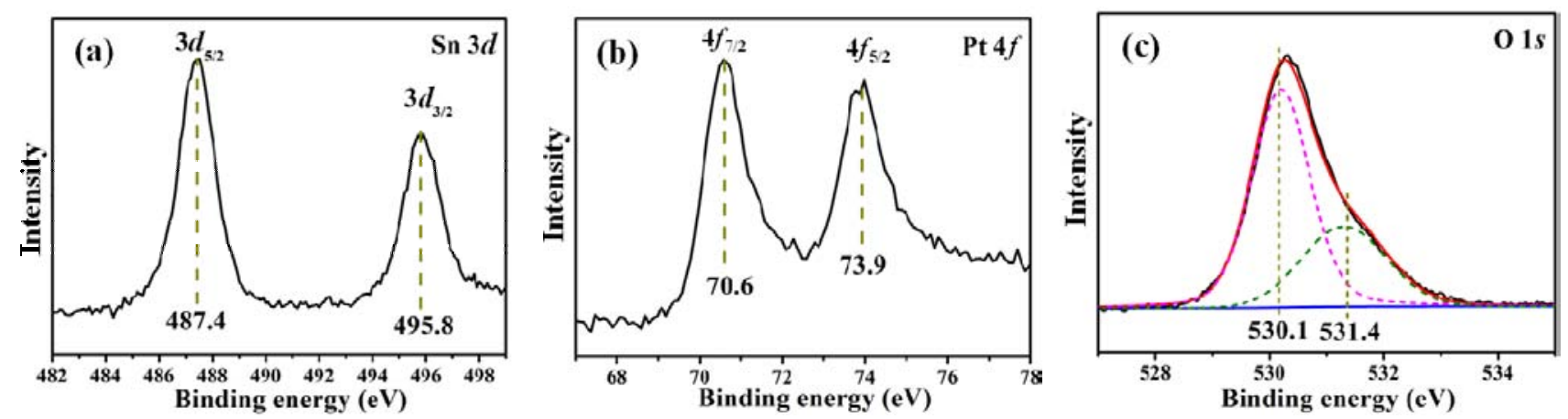

Fig. 4. High resolution XPS spectra for $\mathrm{Sn} 3 d$ (a), $\mathrm{Pt} 4 f(\mathrm{~b})$ and $\mathrm{O} 1 s$ (c) orbits of $\mathrm{Pt} / \mathrm{SnO}_{x}$.

els of Sn(IV) [52], indicating that the surface of the SnO support was oxidized in air [53]. This was consistent with the XRD data. The chemical state of the Pt NPs was also identified from the two Pt $4 f$ peaks located at $70.6 \mathrm{eV}\left(\mathrm{Pt} 4 f_{7 / 2}\right)$ and $73.9 \mathrm{eV}(\mathrm{Pt}$ 4f5/2) (Fig. 4(b)), confirming the presence of metallic Pt [36]. The 01 XPS spectrum (Fig. 4(c)) was decomposed into two components at 530.1 and $531.4 \mathrm{eV}$, corresponding to surface lattice oxygen and hydroxyl oxygen, respectively [53].

\subsection{Textural properties}

The hierarchical architecture was not only identified by SEM and TEM (Fig. 1), but also confirmed by the $\mathrm{N}_{2}$ adsorption isotherm and pore size distribution curve (Fig. 5(a)). The isotherms of $\mathrm{SnO}_{x}$ and $\mathrm{Pt} / \mathrm{SnO}_{x}$ were Type IV, characteristic of materials with a mesoporous structure [54]. The hysteresis loops were Type $\mathrm{H} 3$ in the high relative pressure $\left(p / p_{0}\right)$ range of $0.5-1.0$, indicating the presence of slit-like mesopores formed by the assembly of nanosheets/nanoplates [54]. The isotherms showed high adsorption values at relative pressures approaching 1.0, which is typical for materials with large mesopores and macropores.

The BET specific surface area ( $\left.S_{\mathrm{BET}}\right)$ for the $\mathrm{SnO}_{x}$ and $\mathrm{Pt} / \mathrm{SnO}_{x}$ samples was 24 and $21 \mathrm{~m}^{2} / \mathrm{g}$, respectively (Table 1 ). The BJH pore size distribution curves displayed three peaks at 3, 14 and $25 \mathrm{~nm}$ for $\mathrm{SnO}_{x}$ (Fig. 5(a)). The major peak at $3 \mathrm{~nm}$

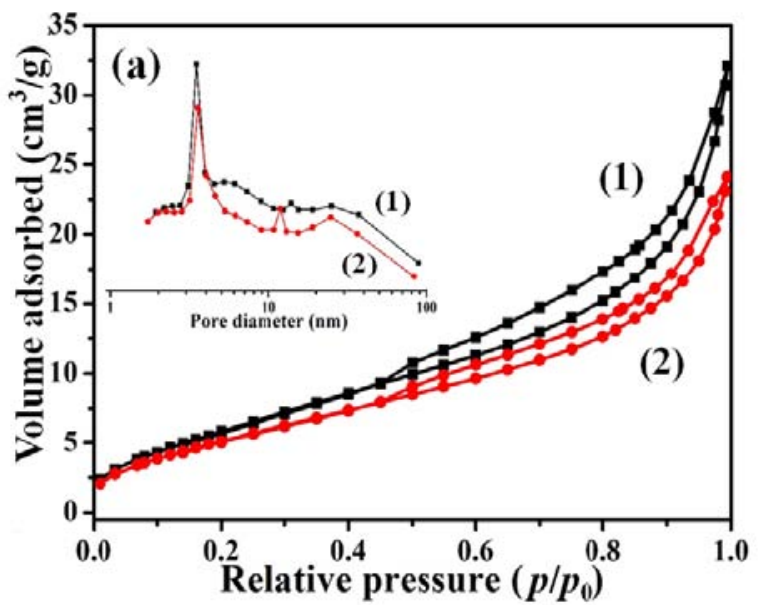

Table 1

Textural properties and $\mathrm{HCHO}$ removal performance of the samples.

\begin{tabular}{lcccccc}
\hline Sample & $\begin{array}{c}S_{\mathrm{BET}^{\mathrm{a}}} \\
\left(\mathrm{m}^{2} / \mathrm{g}\right)\end{array}$ & $\begin{array}{c}V_{\mathrm{p}} \mathrm{b} \\
\left(\mathrm{cm}^{3} / \mathrm{g}\right)\end{array}$ & $\begin{array}{c}d_{\mathrm{p}} \mathrm{c} \\
(\mathrm{nm})\end{array}$ & $\begin{array}{c}\eta^{\mathrm{d}} \\
(\%)\end{array}$ & $\begin{array}{c}k^{\mathrm{e}} \\
\left(\mathrm{ppm}^{-1} \cdot \mathrm{min}^{-1}\right)\end{array}$ & $R^{2}$ \\
\hline $\mathrm{SnO}_{\mathrm{x}}$ & 24 & 0.04 & 7 & 10 & $0.1 \times 10^{-4}$ & 0.994 \\
$\mathrm{Pt}_{\mathrm{SnO}} \mathrm{x}$ & 21 & 0.03 & 6 & 87 & $6.7 \times 10^{-4}$ & 0.994 \\
$\mathrm{Pt} / \mathrm{c}-\mathrm{SnO}$ & 3 & 0.004 & 5 & 73 & $2.7 \times 10^{-4}$ & 0.999 \\
$\mathrm{Pt} / \mathrm{g}-\mathrm{SnO}_{\mathrm{x}}$ & 18 & 0.05 & 12 & 57 & $1.2 \times 10^{-4}$ & 0.996 \\
\hline
\end{tabular}

Notes: a BET specific surface area; ${ }^{b}$ pore volume; ${ }^{c}$ average pore size; ${ }^{d} \mathrm{HCHO}$ removal ratio after $1 \mathrm{~h}$ of reaction; e second-order rate constant.

was attributed to the small mesopores on the nanosheets, and the intensity of this peak decreased after the deposition of $\mathrm{Pt}$ NPs. This change indicated that the small mesopores on the $\mathrm{SnO}_{x}$ nanosheets were covered by Pt NPs.

The $\mathrm{N}_{2}$ adsorption isotherm of Pt/g-SnO $x$ (Fig. 5(b)) was also Type IV with a Type H3 hysteresis loop, but the pore size distribution of the sample was significantly changed after ball-milling. The large pores became more abundant and the smaller pores centered around $3 \mathrm{~nm}$ decreased. Correspondingly, the pore volume and average pore size increased, while

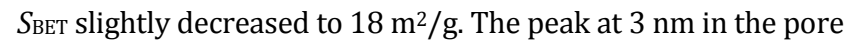
size distribution curve of Pt-g-SnO ${ }_{x}$ (inset of Fig. 5(b)) further suggested that these smaller mesopores were present on the nanosheets.

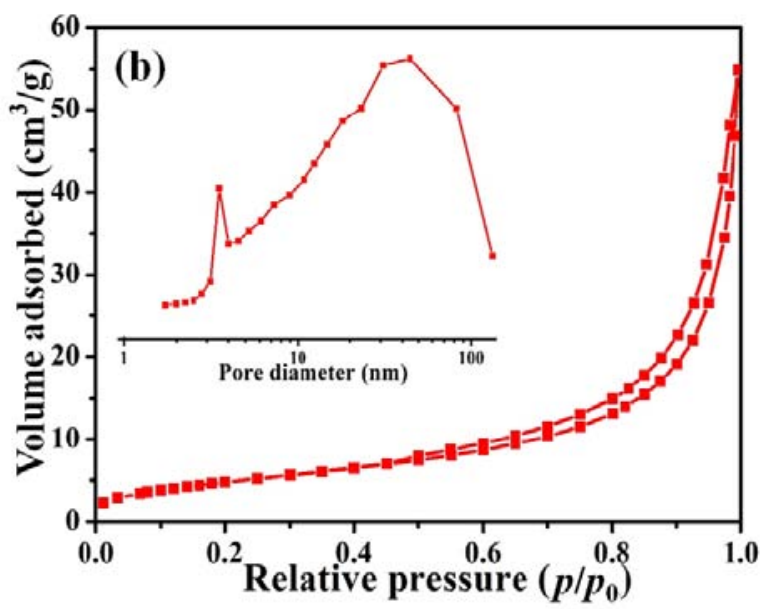

Fig. 5. (a) $\mathrm{N}_{2}$ adsorption isotherm and pore size distribution (inset) for $\mathrm{SnO}_{x}(1)$ and $\mathrm{Pt}_{\mathrm{SnO}}$ (2); (b) $\mathrm{N}_{2}$ adsorption isotherm and pore size distribution (inset) for Pt/g-SnO 

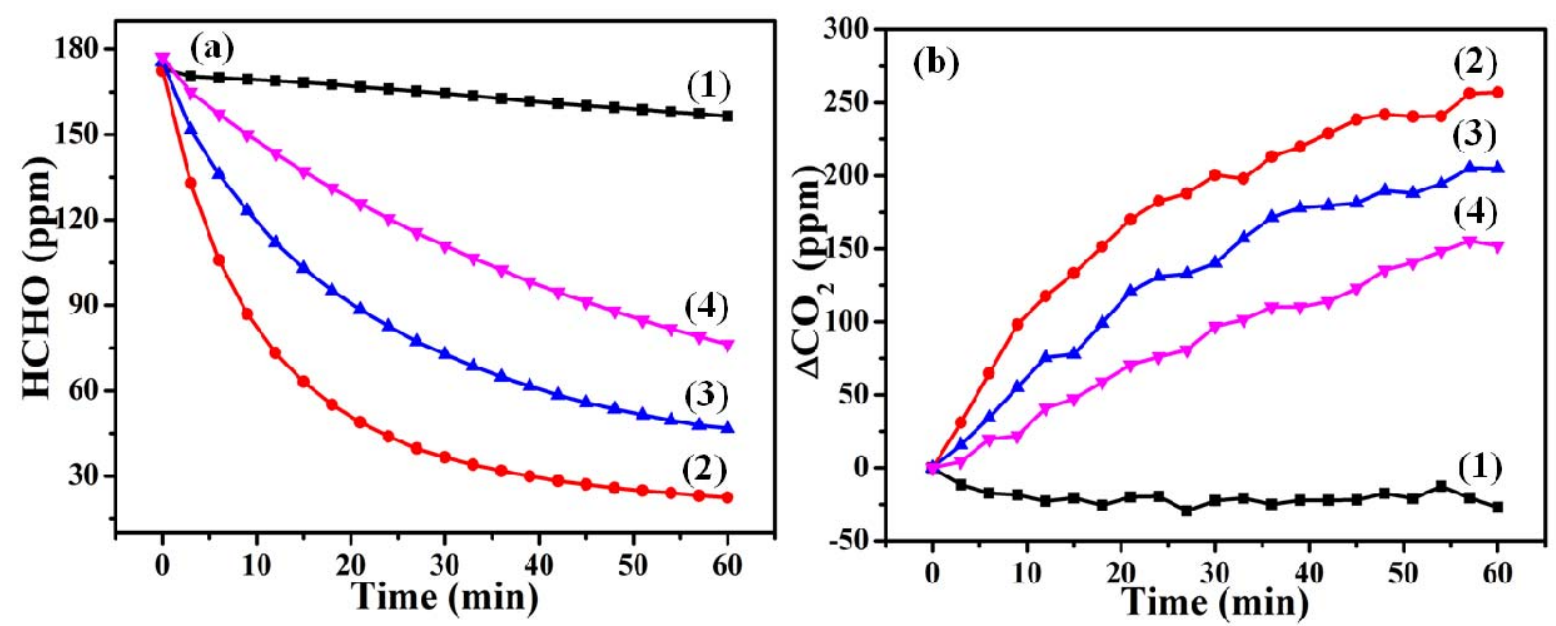

Fig. 6. Change of $\mathrm{HCHO}$ concentration (a) and $\Delta \mathrm{CO}_{2}\left(\mathrm{CO}_{2}\right.$ concentration change relative to background level) (b) versus time for different samples: (1) $\mathrm{SnO}_{x}$; (2) $\mathrm{Pt} / \mathrm{SnO}_{x} ;$ (3) Pt/c-SnO; (4) Pt/g-SnO .

\subsection{Catalytic activity}

The room temperature catalytic HCHO oxidation performance is shown in Fig. 6. When the flower-like $\mathrm{SnO}_{x}$ was tested, the HCHO concentration was only slightly decreased from 173 to $156 \mathrm{ppm}$ after $1 \mathrm{~h}$ of reaction (Fig. 6(a)), while the $\mathrm{CO}_{2}$ concentration in the reactor was also slightly decreased (Fig. 6(b)) due to adsorption on the porous $\mathrm{SnO}_{x}$. This suggested that the flower-like $\mathrm{SnO}_{x}$ alone cannot catalyze the oxidative decomposition of $\mathrm{HCHO}$ into $\mathrm{CO}_{2}$ and $\mathrm{H}_{2} \mathrm{O}$. Instead, $\mathrm{HCHO}$ was removed from the gas phase by adsorption. In contrast, in the presence of $\mathrm{Pt} / \mathrm{SnO}_{x}$, the $\mathrm{HCHO}$ concentration decreased from 172 to 23 ppm after $1 \mathrm{~h}$ of reaction corresponding to a HCHO removal of $87 \%$, and the $\mathrm{CO}_{2}$ concentration in the reactor increased over the $1 \mathrm{~h}$, indicating that the supported Pt NPs were the active components for catalytic HCHO oxidation. No CO was detected (data not shown) suggesting the complete oxidation of HCHO. It should be noted that the increase in the $\mathrm{CO}_{2}$ concentration was larger than the change in the HCHO concentration. This discrepancy was due to: (1) the oxidation of HCHO molecules adsorbed onto the reactor walls and gradually desorbed as the decomposition reaction proceeded; (2) inaccuracy of the $\mathrm{CO}_{2}$ measurement [15].

The HCHO removal ratio over the commercial SnO-supported Pt (Pt/c-SnO) was lower than that over Pt/SnO which was partly due to the smaller specific surface area of $\mathrm{Pt} / \mathrm{c}-\mathrm{SnO}$ (Table 1). On the other hand, the ground $\mathrm{SnO}_{x}$-supported Pt $\left(\mathrm{Pt} / \mathrm{g}\right.$-SnO $x$ ) had a slightly smaller $S_{\mathrm{BET}}$ than $\mathrm{Pt} / \mathrm{SnO}_{x}$, but its $\mathrm{HCHO}$ oxidation activity was much lower, with the HCHO concentration decreasing from 177 to 76 ppm after 1 $\mathrm{h}$ of reaction (Fig. 6(a)) corresponding to a HCHO removal of $57 \%$. These results suggested that the high HCHO removal efficiency of $\mathrm{Pt} / \mathrm{SnO}_{x}$ was not only because of the larger specific area but also due to the flower-like hierarchical structure.

The stability of the catalytic performance is another important factor to consider in designing a catalyst. Thus, the catalytic oxidation of $\mathrm{HCHO}$ over $\mathrm{Pt} / \mathrm{SnO}_{x}$ at room temperature was performed with the same catalyst six times (Fig. 7). After six cycles, the catalytic activity of $\mathrm{Pt} / \mathrm{SnO}_{x}$ was not changed significantly as compared with that in the first cycle, indicating that the $\mathrm{Pt} / \mathrm{SnO}_{x}$ catalyst maintained a stable and efficient catalytic performance.

\subsection{Reaction kinetics and mechanism}

In order to gain a deeper understanding of the catalytic $\mathrm{HCHO}$ oxidation process over $\mathrm{Pt} / \mathrm{SnO}_{x}$ at room temperature, we explored the reaction kinetics and mechanism. While the catalytic oxidation of $\mathrm{HCHO}$ in the presence of oxygen can generally be described by first order or pseudo-first order kinetics $[26,55]$, first order fitting did not yield satisfactory results for our data. Thus, we further studied the reaction kinetics using the second order kinetic rate equation:

$$
\frac{1}{C_{t}}-\frac{1}{C_{0}}=k t
$$

where $C_{t}(\mathrm{ppm})$ is the HCHO concentration at time $t$ (min), and $k$ is the second order rate constant $\left(\mathrm{ppm}^{-1} \cdot \mathrm{min}^{-1}\right)$.

From the linear plot of $1 / C_{t}$ versus $t$ (Fig. 8), the rate con-

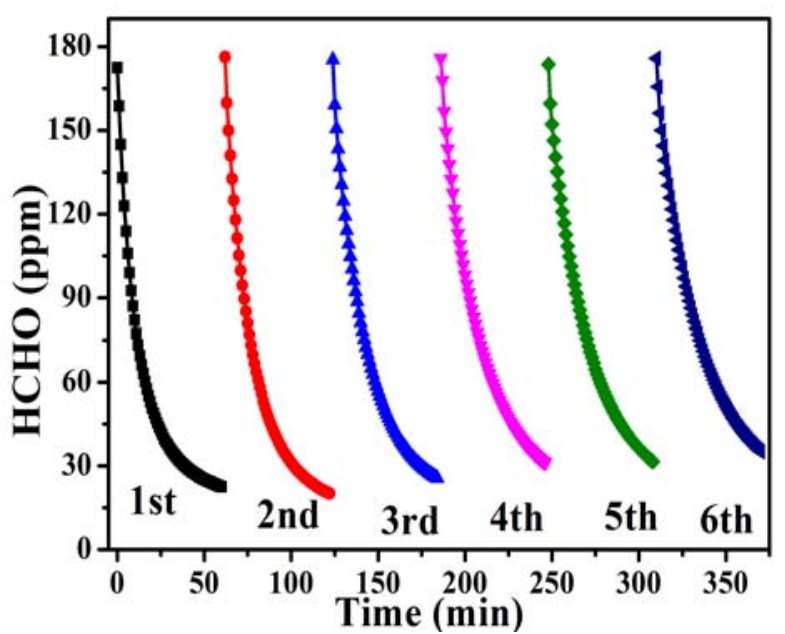

Fig. 7. Recycling test of $\mathrm{HCHO}$ oxidative decomposition over $\mathrm{Pt} / \mathrm{SnO}_{x}$ at room temperature. 


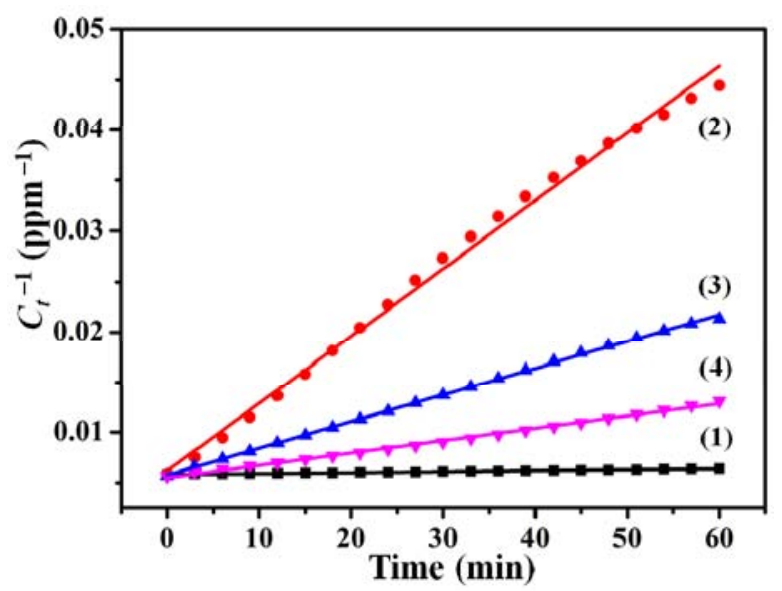

Fig. 8. Second order kinetics for $\mathrm{HCHO}$ oxidation of (1) $\mathrm{SnO}_{x}$, (2) $\mathrm{Pt} / \mathrm{SnO}_{x},(3) \mathrm{Pt} / \mathrm{c}-\mathrm{SnO}$ and (4) Pt/g-SnO .

stants $k$ and correlation coefficient $\left(R^{2}\right)$ for the samples were calculated (Table 1). The $R^{2}$ values were larger than 0.993 for all samples, indicating that it is reasonable to suppose that the catalytic removal of HCHO over the samples followed second order reaction kinetics. From Fig. 8 and Table 1, the $k$ value for $\mathrm{Pt} / \mathrm{SnO}_{x}\left(6.7 \times 10^{-4} \mathrm{ppm}^{-1} \cdot \mathrm{min}^{-1}\right)$ was 2.5 and 5.6 times higher than those for Pt/c-SnO $\left(2.7 \times 10^{-4} \mathrm{ppm}^{-1} \cdot \mathrm{min}^{-1}\right)$ and Pt/g-SnO $\left(1.2 \times 10^{-4} \mathrm{ppm}^{-1} \cdot \mathrm{min}^{-1}\right)$, suggesting that the rate of the reaction can be greatly increased and that the flower-like hierarchical architecture of $\mathrm{SnO}_{x}$ played a crucial role in improving the catalytic performance.

A reaction mechanism (Fig. 9) for the room temperature catalytic oxidation of $\mathrm{HCHO}$ over $\mathrm{Pt} / \mathrm{SnO}_{x}$ can be proposed. First, $\mathrm{HCHO}$ and $\mathrm{O}_{2}$ molecules diffuse into $\mathrm{Pt} / \mathrm{SnO}_{x}$ through the hierarchical pore structure and adsorb on the $\mathrm{SnO}_{x}$ nanosheets and Pt NPs, respectively (step I). In this step, HCHO molecules interact with the surface hydroxyl groups of $\mathrm{SnO}_{x}$ by hydrogen bonding, while the $\mathrm{O}_{2}$ molecules were converted to active $\mathrm{O}$ atoms on the metallic Pt NPs [15,16]. Then, absorbed HCHO was oxidized to formic acid $(\mathrm{HCOOH})$ by the active $\mathrm{O}$ atom on the Pt NP surface (step II). The $\mathrm{HCOOH}$ molecule was further oxidized to carbonic acid $\left(\mathrm{H}_{2} \mathrm{CO}_{3}\right)$ by another active $\mathrm{O}$ atom

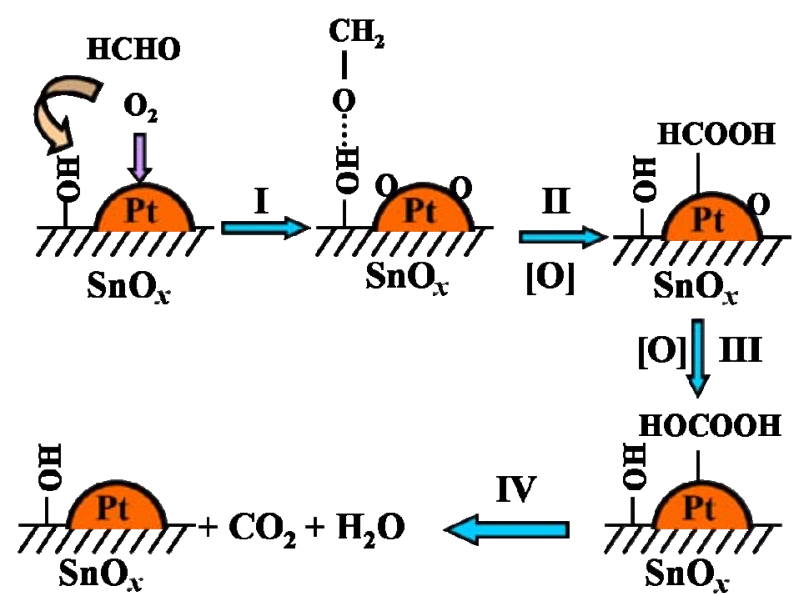

Fig. 9. Schematic of the reaction mechanism for the catalytic oxidation of $\mathrm{HCHO}$ on the $\mathrm{Pt} / \mathrm{SnO}_{x}$ catalyst. (step III), and finally $\mathrm{H}_{2} \mathrm{CO}_{3}$ decomposed into $\mathrm{CO}_{2}$ and $\mathrm{H}_{2} \mathrm{O}$, which desorbed from the catalyst surface and were quickly transported to the bulk gas phase through the hierarchical structure (step IV).

\section{Conclusions}

We synthesized a $\mathrm{Pt} / \mathrm{SnO}_{x}$ catalyst with a hierarchical flower-like structure for efficient catalytic oxidation of $\mathrm{HCHO}$ into $\mathrm{CO}_{2}$ and $\mathrm{H}_{2} \mathrm{O}$ at room temperature. Compared with a commercial SnO-supported $\mathrm{Pt}$ and other catalysts, $\mathrm{Pt} / \mathrm{SnO}_{x}$ with the hierarchical structure exhibited superior catalytic performance, which was shown by a high HCHO removal and large rate constant as well as high stability. The good performance of the catalyst was due to: (1) the hierarchical flower-like architecture, which facilitated the diffusion of HCHO into the catalyst, and (2) the high dispersion of Pt NPs, which were the active sites for $\mathrm{HCHO}$ oxidation. The flower-like $\mathrm{Pt} / \mathrm{SnO}_{x}$ catalyst is a promising material for indoor HCHO removal and is also applicable to the abatement of other indoor air pollutants. The results of this study provide a strategy for designing a hierarchical catalyst for applications in environmental catalysis.

\section{References}

[1] T. Salthammer, S. Mentese, R. Marutzky, Chem. Rev., 2010, 110, 2536-2572.

[2] C. J. Jiang, S. S. Li, P. Y. Zhang, J. Wang, Build. Environ., 2013, 69, 227-232.

[3] W. H. Liang, S. Yang, X. D. Yang, Environ. Sci. Technol., 2015, 49, 10349-10356.

[4] Z. H. Xu, J. G. Yu, J. X. Low, M. Jaroniec, ACS Appl. Mater. Interfaces, 2014, 6, 2111-2117.

[5] F. Lin, G. Q. Zhu, Y. N. Shen, Z. Y. Zhang, B. Dong, Appl. Surf. Sci., 2015, 356, 150-156.

[6] F. Chen, S. W. Liu, J. G. Yu, Phys. Chem. Chem. Phys., 2016, 18, 18161-18168.

[7] Z. N. Han, V. W. Chang, X. P. Wang, T. T. Lim, L. Hildemann, Chem. Eng. J., 2013, 218, 9-18.

[8] J. G. Yu, S. H. Wang, J. X. Low, W. Xiao, Phys. Chem. Chem. Phys., 2013, 15, 16883-16890.

[9] C. L. Wu, Appl. Surf. Sci., 2014, 319, 237-243.

[10] X. B. Zhu, D. L. Chang, X. S. Li, Z. G. Sun, X. Q. Deng, A. M. Zhu, Chem. Eng. J., 2015, 279, 897-903.

[11] P. F. Fu, P. Y. Zhang, Chin. J. Catal., 2014, 35, 210-218.

[12] C. B. Zhang, H. He, K. I. Tanaka, Catal. Commun., 2005, 6, 211-214.

[13] H. B. Huang, D. Y. C. Leung, J. Catal., 2011, 280, 60-67.

[14] C. B. Zhang, F. D. Liu, Y. P. Zhai, H. Ariga, N. Yi, Y. C. Liu, K. Asakura, M. Flytzani-Stephanopoulos, H. He, Angew. Chem. Int. Ed., 2012, $51,9628-9632$.

[15] Z. X. Yan, Z. H. Xu, J. G. Yu, M. Jaroniec, Environ. Sci. Technol., 2015, $49,6637-6644$.

[16] Z. H. Xu, J. G. Yu, M. Jaroniec, Appl. Catal. B, 2015, 163, 306-312.

[17] H. Y. Chen, Z. B. Rui, H. B. Ji, Chin. J. Catal., 2015, 36, 188-196.

[18] Y. Ma, G. K. Zhang, Chem. Eng. J., 2016, 288, 70-78.

[19] H. B. Huang, D. Y. C. Leung, ACS Catal., 2011, 1, 348-354.

[20] S. J. Park, I. Bae, I. S. Nam, B. K. Cho, S. M. Jung, J. H. Lee, Chem. Eng. J., 2012, 195-196, 392-402.

[21] H. F. Li, N. Zhang, P. Chen, M. F. Luo, J. Q. Lu, Appl. Catal. B, 2011, $110,279-285$. 


\section{Graphical Abstract}

Chin. J. Catal., 2017, 38: 199-206 doi: 10.1016/S1872-2067(16)62551-2

Effects of hierarchical structure on the performance of tin oxide-supported platinum catalyst for room-temperature formaldehyde oxidation

Yuanyuan Duan, Shaoqing Song, Bei Cheng, Jiaguo Yu*, Chuanjia Jiang *

Wuhan University of Technology, China; East China University of Technology, China; King Abdulaziz University, Saudi Arabia

Pt nanoparticles (NPs) supported on a hierarchical flower-like $\mathrm{SnO}_{x}\left(\mathrm{Pt} / \mathrm{SnO}_{x}\right)$ exhibited enhanced activity for room temperature catalytic oxidation of formaldehyde compared to Pt NPs on commercial $\mathrm{SnO}$ or ground $\mathrm{SnO}_{x}$.
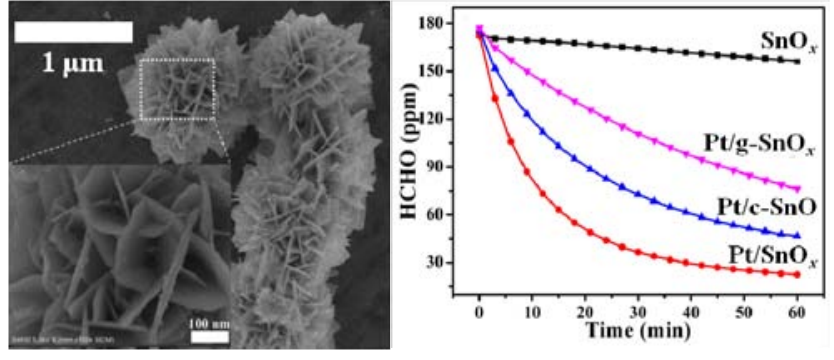

[22] Q. L. Xu, W. Y. Lei, X. Y. Li, X. Y. Qi, J. G. Yu, G. Liu, J. L. Wang, P. Y. Zhang, Environ. Sci. Technol., 2014, 48, 9702-9708.

[23] Z. Tang, W. D. Zhang, Y. Li, Z. M. Huang, H. S. Guo, F. Wu, J. J. Li, Appl. Surf. Sci., 2016, 364, 75-80.

[24] B. Y. Bai, J. H. Li, ACS Catal., 2014, 4, 2753-2762.

[25] M. A. Sidheswaran, H. Destaillats, D. P. Sullivan, J. Larsen, W. J. Fisk, Appl. Catal. B, 2011, 107, 34-41.

[26] J. L. Wang, P. Y. Zhang, J. G. Li, C. J. Jiang, R. Yunus, J. Kim, Environ. Sci. Technol., 2015, 49, 12372-12379.

[27] J. L. Wang, R. Yunus, J. G. Li, P. L. Li, P. Y. Zhang, J. Kim, Appl. Surf. Sci., 2015, 357, 787-794.

[28] B. Y. Bai, Q. Qiao, J. H. Li, J. M. Hao, Chin. J. Catal, 2016, 37, 27-31.

[29] Z. Y. Fan, Z. X. Zhang, W. J. Fang, X. Yao, G. C. Zou, W. F. Shangguan, Chin. J. Catal., 2016, 37, 947-954.

[30] L. H. Nie, J. G. Yu, M. Jaroniec, F. F. Tao, Catal. Sci. Technol, 2016, 6, 3649-3669.

[31] B. Y. Bai, Q. Qiao, J. H. Li, J. M. Hao, Chin. J. Catal., 2016, 37, 102-122.

[32] J. X. Peng, S. D. Wang, Appl. Catal. B, 2007, 73, 282-291.

[33] X. F. Zhu, B. Cheng, J. G. Yu, W. K. Ho, Appl. Surf. Sci., 2016, 364, 808-814.

[34] M. Al-Halhouli, J. Kieninger, O. Yurchenko, G. Urban, Appl. Catal. A, 2016, 517, 12-20.

[35] M. Vaclavik, V. Novak, J. Brezina, P. Koci, G. Gregori, D. Thompsett, Catal. Today, 2016, 273, 112-120.

[36] L. H. Nie, J. G. Yu, J. W. Fu, ChemCatChem, 2014, 6, 1983-1989.

[37] L. F. Qi, W. K. Ho, J. L. Wang, P. Y. Zhang, J. G. Yu, Catal. Sci. Technol,, 2015, 5, 2366-2377.

[38] Y. G. Guo, J. S. Hu, L. J. Wan, Adv. Mater, 2008, 20, 2878-2887.

[39] Y. Li, Z. Y. Fu, B. L. Su, Adv. Funct. Mater., 2012, 22, 4634-4667.
[40] J. H. Lee, Sens. Actuator B, 2009, 140, 319-336.

[41] B. Cheng, Y. Le, W. Q. Cai, J. G. Yu, J. Hazard. Mater., 2011, 185, 889-897.

[42] Q. C. Liu, D. K. Ma, Y. Y. Hu, Y. W. Zeng, S. M. Huang, ACS Appl. Mater. Interfaces, 2013, 5, 11927-11934.

[43] J. G. Yu, Y. R. Su, B. Cheng, Adv. Funct. Mater., 2007, 17, 1984-1990.

[44] L. Liu, H. J. Liu, Y. P. Zhao, Y. Q. Wang, Y. Q. Duan, G. D. Gao, M. Ge, W. Chen, Environ. Sci. Technol., 2008, 42, 2342-2348.

[45] Z. H. Ai, W. K. Ho, S. C. Lee, L. Z. Zhang, Environ. Sci. Technol., 2009, $43,4143-4150$.

[46] W. G. Wang, J. G. Yu, Q. J. Xiang, B. Cheng, Appl. Catal. B, 2012, 119-120, 109-116.

[47] J. W. Ng, X. P. Wang, D. D. Sun, Appl. Catal. B, 2011, 110, 260-272.

[48] R. A. He, S. W. Cao, J. G. Yu, Y. C. Yang, Catal. Today, 2016, 264, 221-228.

[49] X. Li, J. G. Yu, M. Jaroniec, Chem. Soc. Rev., 2016, 45, 2603-2636.

[50] J. Jin, J. G. Yu, D. P. Guo, C. Cui, W. K. Ho, Small, 2015, 11, 5262-5271.

[51] A. Y. Meng, J. Zhang, D. F. Xu, B. Cheng, J. G. Yu, Appl. Catal. B, 2016, 198, 286-294.

[52] J. F. Moulder, W. F. Stickle, P. E. Sobol, K. D. Bomben, Handbook of $X$-ray Photoelectron Spectroscopy, Perkin-Elmer Corporation, Eden Prairie, 1992.

[53] Y. C. Yang, J. Liu, C. Li, L. Fu, W. Huang, Z. L. Li, Electrochim. Acta, 2012, 72, 94-100.

[54] K. S. W. Sing, D. H. Everett, R. A. W. Haul, L. Moscou, R. A. Pierotti, J. Rouquerol, T. Siemieniewska, Pure Appl. Chem., 1985, 57, 603-619.

[55] S. K. Shin, J. H. Song, J. Hazard. Mater., 2011, 194, 385-392.

\section{分等级结构对锡氧化物负载 Pt 室温催化甲醛氧化性能的影响

\author{
段媛媛 ${ }^{\mathrm{a}}$, 宋少青 ${ }^{\mathrm{b}}$, 程 蓓 ${ }^{\mathrm{a}}$, 余家国 ${ }^{\mathrm{a}, \mathrm{c}, *}$, 姜传佳 ${ }^{\mathrm{a}, \#}$ \\ a武汉理工大学材料复合新技术国家重点实验室, 湖北武汉 430070 \\ “沙特阿卜杜勒阿齐兹国王大学科学部物理系, 吉达21589, 沙特阿拉伯
} \\ ${ }^{\mathrm{b}}$ 东华理工大学放射性地质与勘探技术国防重点学科实验室, 江西南昌330013}

摘要: 甲醛是主要的室内空气污染物, 气相中甲醛去除技术具有重要意义. 常用的甲醛去除技术主要包括物理和化学吸 附、光催化分解和热催化氧化, 其中能在常温下进行的催化氧化最具发展和实用前景. 能在室温下高效催化甲醛完全氧化 的催化剂一般为负载型贵金属, 如铂 $(\mathrm{Pt})$ 、钯、金、银等. 除了选择具有内在高活性的组分, 通过提高贵金属分散度, 增强 贵金属-载体相互作用, 增加载体的甲醛亲和性等方法也可提高甲醛催化分解活性. 以上方法主要关注催化剂化学性质的 
改良; 另一方面, 催化剂的微观几何结构以及传质快慢对表观催化反应速率也有重要影响. 近年来研究表明, 分等级结构 利于反应物在材料孔隙中的扩散输移, 可大幅提高催化活性. 因此, 我们制备了具有分等级结构的花状锡氧化物 $\left(\mathrm{SnO}_{x}\right)$ 负 载的 Pt 纳米颗粒, 并研究其室温下催化分解甲酫的性能.

花状 $\mathrm{SnO}_{x}$ 以氟化亚锡和尿素为原料, 通过水热法制备; Pt 通过浸渍、嗍氢化钠还原法负载, 制备 $\mathrm{Pt} / \mathrm{SnO}_{x}$ 催化剂. 另外, 对 $\mathrm{SnO}_{x}$ 进行球磨处理破坏其分等级结构, 制备 $\mathrm{g}-\mathrm{SnO}_{x}$ 及 $\mathrm{Pt} / \mathrm{g}-\mathrm{SnO}_{x}$ 作为对照. 通过场发射扫描电镜观察, 制备的锡氧化物 为具有分等级结构的花状微球, 直径约 $1 \mu \mathrm{m}$, 由厚度约 $20 \mathrm{~nm}$ 的花瓣状纳米片交错连接而成. $\mathrm{X}$ 射线衍射 (XRD) 谱图对 应四方相氧化亚锡 (SnO, JCPDS 06-0395), 但也观察到四方金红石相氧化锡 $\left(\mathrm{SnO}_{2}, \mathrm{JCPDS} 41-1445\right)$ 的微弱特征峰. 高分辨 透射电镜 (HRTEM) 仅观察到四方相 SnO 的晶格条纹. 根据 X 射线光电子能谱 (XPS) 结果, 在花状锡氧化物的表面, 锡元 素的氧化态为正四价. 综合以上表征结果表明: 制备的锡氧化物主体为 $\mathrm{SnO}$, 由于表面被空气氧化, 含有少量 $\mathrm{SnO}_{2}$. 通过 透射电镜观察 $\mathrm{Pt} / \mathrm{SnO}_{x}$ 催化剂发现, 直径 2-3 nm 的 Pt 纳米颗粒高度分散负载于 $\mathrm{SnO}_{x}$ 纳米片表面; XPS 结果表明, 纳米颗 粒中 Pt 的价态为 0 价, 与 HRTEM 观测结果一致.

甲醛分解测试采用静态测试系统, 在体积为 $6 \mathrm{~L}$ 的测试箱中加入一定浓度甲醛后开始反应, 监测甲醛、二氧化碳 $\left(\mathrm{CO}_{2}\right)$ 和一氧化碳 (CO) 浓度随时间的变化. 结果表明, 花状 $\mathrm{SnO}_{x}$ 在室温下不具有催化甲醛氧化活性, 仅能通过吸附作用去除少 量甲醛; 而负载 0 价金属态 $\mathrm{Pt}$ 纳米颗粒后, 甲醴快速分解为 $\mathrm{CO}_{2}$ 和水, 且无 $\mathrm{CO}$ 生成. 在初始浓度 $170 \mathrm{ppm}$ 条件下, 反应 1 $\mathrm{h}$ 后, 甲醛去除率达到 $87 \% . \mathrm{Pt} / \mathrm{SnO}_{x}$ 催化剂的高活性表明, 金属态 $\mathrm{Pt}$ 是催化甲醛氧化的活性组分. 经球磨处理后制备的 $\mathrm{Pt} / \mathrm{g}-\mathrm{SnO}_{x}$, 其催化活性远低于具有分等级结构的 $\mathrm{Pt} / \mathrm{SnO}_{x}$; 后者的二级反应速率常数为前者的 5.6 倍, 证明分等级结构能有 效加速甲醛催化氧化分解. 本研究结果对于高效分解室内甲醛材料的设计、制备提供了一种指导性的新思路.

关键词: 催化甲酫氧化; 室温; 锡氧化物; 铂; 分等级结构; 花状

收稿日期: 2016-08-22. 接受日期: 2016-10-06. 出版日期: 2017-02-05.

*通讯联系人. 电话: (027) 87871029; 传真: (027) 87879468; 电子信箱: jiaguoyu@yahoo.com

通讯联系人. 电话: (027) 87871029; 传真: (027) 87879468; 电子信箱: jiangcj2016@yahoo.com

基金来源: 国家自然科学基金 (51320105001，51372190，21573170, 51272199, 21433007), 国家重点基础研究发展计划 (973 计划, 2013CB632402), 湖北省自然科学基金 (2015CFA001), 中央高校基本科研基金 (WUT: 2015-III-034), 武汉理工大学材料复合新 技术国家重点实验室创新基金 (2015-ZD-1).

本文的英文电子版由Elsevier出版社在ScienceDirect上出版(http://www.sciencedirect.com/science/journal/18722067). 